\title{
PHYSICOCHEMICAL AND SENSORY CHARACTERISTICS OF FINE SPARKLING RED WINES PRODUCED AT DIFFERENT MACERATION LENGTHS IN THE SOUTH OF BRAZIL
}

\author{
CARACTERÍSTICAS FÍSICO-QUÍMICAS E SENSORIAIS DE VINHOS \\ ESPUMANTES FINOS TINTOS PRODUZIDOS A PARTIR DE DIFERENTES \\ PERÍODOS DE MACERAÇÃO NO SUL DO BRASIL
}

\section{Rafaela Gadret RIZZOLO ${ }^{1}$; Celito Crivellaro GUERRA²; Gisele Eliane PERISSUTTI ${ }^{2}$; Raul Luiz BEN ${ }^{2}$; Renan NAVROSKI ${ }^{1}$; Marcelo Barbosa MALGARIM ${ }^{1}$}

1. Federal University of Pelotas, Department of Plant Sciences, Fruit-Growing Laboratory, Pelotas, RS, Brazil; 2. Brazilian Agricultural Research Corporation, National Grape and Wine Research Center, Bento Gonçalves, RS, Brazil. celito.guerra@embrapa.br

\begin{abstract}
Maceration is the step of the vinification process in which phenolic and aromatic compounds are transferred to wine. This study aimed at producing fine sparkling red wines by testing different grape varieties and maceration lengths. Grapes underwent maceration for 24 hours (Very Short Maceration - VSM) and for 48 hours (Short Maceration - SM). Sparkling wines were produced by the traditional method and analyses were carried out in the must, base wines and sparkling wines. Analyzes of minerals, volatile compounds and physicochemicals related to total soluble solids (TSS), Volatile Acidity (VA); Free Sulfur Dioxide (Free $\mathrm{SO}_{2}$ ); Total Sulfur Dioxide (Total $\mathrm{SO}_{2}$ ); Total Titratable Acidity (TTA); Fixed Acidity (FA); Hydrogenionic Potential (pH); Alcoholic Content (AC); Reduced Dry Extract (RDE); Total Tannins (TT); Total Anthocyanins (TA); Total Polyphenol Content (TPC); Total Color Intensity (TCI). In addition, during the tasting, a quantitative and descriptive record was distributed to the researchers to characterize the wines in relation to color, perlage, aroma, flavor, main descriptor of the aroma and main general adjective. The sparkling wines which had the best evaluations at different maceration lengths were the following: sparkling wine 100\% Teroldego (SM) and sparkling wine $62.5 \%$ Teroldego, $18.75 \%$ Merlot and $18.75 \%$ Pinot (SM). Both short maceration (48 hours) and the Teroldego variety were the vinification parameters which provided the best olfactory-gustatory and color characteristics to the sparkling wines under study. All sparkling wines had enological potential to be vinified in red. Maturation and maceration processes under evaluation produced the typical freshness of sparkling wines and the desired red color.
\end{abstract}

KEYWORDS: Assemblage. Combined sparkling wines. Enology. Polyphenols.

\section{INTRODUCTION}

The concentration of the chemical constituents in grapes and consequently in the wines can be influenced by factors including grape variety, environmental conditions, production technology and maceration (CVEJIĆ et al., 2016). Among the variables inherent to the maceration process in red winemaking, the management of the amount of contact time that is allowed between the seeds, skins, and stems (when present) and the fermenting/must and wine is arguably the most critical factor for defining the phenolic profile and sensory properties of the resulting wine (GIL et al. 2012; GONZALEZ-NEVES et al. 2012; CASASSA et al., 2013). The effect of ripeness degree and/or maceration time of grapes have been studied in relation to phenolic composition (FERRERGALLEGO et al., 2012), sensory quality (CADOT et al., 2012), physicochemical properties (MELÉNDEZ et al., 2013), and volatile profile of wines (YILMAZTEKIN et al., 2015).
A range of factors during grape processing, fermentation and aging determine the aroma composition of wine wherein the use of certain production methods may result in its decisive changes. Pre-fermentative maceration increases the amount of volatile compounds derived from grapes into must and wine, and consequently improves the overall aroma of wine (BAVČAR et al., 2011), due to the enhanced extraction of varietal compounds such as terpenes and thiols (LUKIC et al., 2015; RADEKA et al., 2008).

Moreover relevant phenolic compounds are extracted and are important because they define some of the most significant organoleptic attributes in red wines and can alter the tactile sensory attributes (ALEIXANDRE-TUDO et al., 2017; CASASSA; HARBERTSON, 2014). Visual red wine properties are mostly due to anthocyanins, but most importantly by their interactions, reactions and combinations among themselves or with other wine substances (HE et al., 2012). Furthermore, proanthocyanins or tannins are relevant compounds responsible for some of the most appreciated 
mouthfeel attributes, i.e. bitterness and astringency. In this case the molecular size (degree of polymerization), subunit composition and combinations with other wine components influence wine's mouthfeel perception (SMITH et al., 2015).

Therefore, the vinification process determines grape quality and transforms maceration into an important factor in quality wine production. Taking this context into account, this study aimed to vinify fine sparkling red wines by testing the influence of grape maceration so as to get and select innovative products with high intrinsic quality but no technological failures.

\section{MATERIAL AND METHODS}

Fine sparkling red wines were produced with Pinot Noir, Merlot and Teroldego varieties, from vineyards located in Vacaria, RS, Brazil $\left(28^{\circ}\right.$ 34' $08^{\prime \prime} \mathrm{S}$ and $\left.50^{\circ} 46^{\prime} 48^{\prime \prime} \mathrm{W}\right), 987 \mathrm{~m}$ above sea level. The harvest of grapes occurred in 2014/2015 and was based on the degustation of berries and on the analysis of soluble solids by refractometry, both in the vineyard and in the laboratory.

Grapes were picked and stored in a cold chamber at $5^{\circ} \mathrm{C}$. The vinification process started when grapes were placed in a destemming-crushing machine. Afterwards, samples of must were collected and placed in bottles in order to be analyzed and verify grape sanity. The remaining amount was stored in stainless steel vertical tanks. Then, sulfation of $80 \mathrm{mg} \cdot \mathrm{L}^{-1}$ and addition of pectinolytic enzymes were carried out. After passing through the inoculum, the yeast Zymaflore RX60 Saccharomyces cerevisiae was added to the tanks at $30 \mathrm{~g} \cdot \mathrm{hL}^{-1}$, along with the fermentation activator Perdomini-IOC Activit, in order to start fermentation. The procedure occurred in a fermentation room at controlled temperature $\left(20^{\circ} \mathrm{C}\right)$.

While must was kept in the stainless steel tanks, two daily remounting processes were carried out up to disincubation and two maceration lengths were investigated. The first one was called Very Short Maceration (VSM), in which must was kept in contact with the skins in stainless steel tanks for 24 hours, to be disincubated later. The second one was called Short Maceration (SM), in which must was kept in contact with the skins for 48 hours. Then, it underwent disincubation and light pressing of the solid phase. After these maceration lengths, disincubation was carried out. The process consisted in transferring the wine to glass gallons which were closed by Müller valves.

The next step consisted in the passage through malolactic fermentation, whose end was determined when the release of carbon dioxide stopped. Afterwards, base wines were kept in a cold chamber at $0^{\circ} \mathrm{C}$ for 15 days so as to undergo tartaric stabilization. Filtration was carried out by a glass microfiber pre-filter. Base wines were submitted to physicochemical analyses. Then, they were classified into monovarietal, bivarietal and trivarietal to undergo the second fermentation (Tables 1,2 and 3).

Table 1. Information on base wines and monovarietal sparkling wines.

\begin{tabular}{cccc}
\hline Sparkling winer number & Varieties & Percentage & Maceration length \\
\hline 1 & Pinot Noir & 100 & VSM \\
2 & Pinot Noir & 100 & VSM \\
3 & Pinot Noir & 100 & SM \\
4 & Pinot Noir & 100 & SM \\
5 & Merlot & 100 & VSM \\
6 & Merlot & 100 & VSM \\
7 & Merlot & 100 & SM \\
8 & Merlot & 100 & SM \\
9 & Teroldego & 100 & VSM \\
10 & Teroldego & 100 & SM \\
\hline
\end{tabular}

VSM = Very Short Maceration (24 hours); SM = Short Maceration (48 hours) 
Table 2. Information on bivarietal sparkling wines.

\begin{tabular}{cccc}
\hline Sparkling wine number & Varieties (combined sparkling wines) & Percentage & Maceration length \\
\hline 11 & Pinot Noir $(1+2)+$ Merlot $(5+6)$ & $50+50$ & VSM \\
12 & Pinot Noir (3+4)+ Merlot (7+8) & $50+50$ & SM \\
13 & Pinot Noir $(1+2)+$ Teroldego (9) & $50+50$ & VSM \\
14 & Pinot Noir (3+4) + Teroldego (10) & $50+50$ & SM \\
15 & Merlot (5+6)+ Teroldego (9) & $50+50$ & VSM \\
16 & Merlot (7+8)+ Teroldego (10) & $50+50$ & SM \\
\hline
\end{tabular}

VSM = Very Short Maceration (24 hours); SM = Short Maceration (48 hours)

Table 3. Information on trivarietal sparkling wines.

\begin{tabular}{|c|c|c|c|}
\hline $\begin{array}{c}\text { Sparkling wine } \\
\text { number }\end{array}$ & Varieties (combined sparkling wines) & Percentage & $\begin{array}{l}\text { Maceration } \\
\text { length }\end{array}$ \\
\hline 17 & $\begin{array}{c}\text { Pinot Noir }(1+2)+\text { Merlot }(5+6)+\text { Teroldego } \\
(9)\end{array}$ & $\begin{array}{c}62,50+18,75+ \\
18,75\end{array}$ & VSM \\
\hline 18 & Pinot Noir $(3+4)+$ Merlot $(7+8)+$ Teroldego & $\begin{array}{c}62,50+18,75+ \\
18,75\end{array}$ & SM \\
\hline 19 & Pinot Noir $(1+2)+$ Merlot $(5+6)+$ Teroldego & $\begin{array}{c}18,75+62,50+ \\
18,75\end{array}$ & VSM \\
\hline 20 & Pinot Noir $(3+4)+$ Merlot $(7+8)+$ Teroldego & $\begin{array}{c}18,75+62,50+ \\
18,75\end{array}$ & SM \\
\hline 21 & Pinot Noir $(1+2)+$ Merlot $(5+6)+$ Teroldego & $\begin{array}{l}18,75+18,75+ \\
\quad 62,50\end{array}$ & VSM \\
\hline 22 & $\begin{array}{c}\text { Pinot Noir }(3+4)+\text { Merlot }(7+8)+\text { Teroldego } \\
(10)\end{array}$ & $\begin{array}{l}18,75+18,75+ \\
62,50\end{array}$ & SM \\
\hline
\end{tabular}

VSM = Very Short Maceration (24 hours); SM = Short Maceration (48 hours)

In order to start foam removal, a liqueur de tirage, which consisted of the yeast Saccharomyces cerevisiae var. bayanus, at initial amounts of $5 \times 10^{6}$ cells.mL $\mathrm{mL}^{-1}, 24 \mathrm{~g} \cdot \mathrm{L}^{-1}$ sucrose, $60 \mathrm{~g} \cdot \mathrm{hL}^{-1}$ bentonite and $3 \mathrm{~g} \cdot \mathrm{hL}^{-1} \mathrm{SO}_{2}$, was added to the wines. After that, they were bottled, bidules were inserted into with the dregs which resulted from the 90-day fermentation. Afterwards, they underwent the 30-day remuage process and the degorgement. Expedition liquor was then added; it derived from the production surplus of the sparkling wines, with no addition of sugar. Bottles were corked with corks and metal muselets. Sensory analyses were carried out five months after foam removal.

Physicochemical and sensory analyses were in agreement with methodologies described by Rizzon in 2010. Physicochemical analyses comprised soluble solids (TSS), Volatile Acidity (VA); Free Sulfur Dioxide (Free $\mathrm{SO}_{2}$ ); Total Sulfur Dioxide (Total $\mathrm{SO}_{2}$ ); Total Titratable Acidity (TTA); Fixed Acidity (FA); Hydrogenionic Potential (pH); Alcoholic Content (AC); Reduced Dry Extract (RDE); Total Tannins (TT); Total Anthocyanins (TA); Total Polyphenol Content (TPC); Total Color Intensity (TCI), minerals and volatile compounds. The sensory analyzes consisted in distribution of cards with a quantitative part, in which twelve researchers have tasted and gave scores from zero to ten for color, perlage, aroma and flavor, and another qualitative part in which the researchers wrote the aroma main descriptors and main general adjectives.

A Perkin-Elmer flame atomic absorption spectrophotometer, model 2380, was used for determining both minerals sodium $(\mathrm{Na})$ and potassium $(\mathrm{K})$ whereas phosphorus $(\mathrm{P})$ was read by an Agilent Technologies UV-Vis spectrophotometer, model Cary 60. The other determinations of calcium $(\mathrm{Ca})$, magnesium $(\mathrm{Mg})$, manganese $(\mathrm{Mn})$, copper $(\mathrm{Cu})$, iron $(\mathrm{Fe})$, zinc $(\mathrm{Zn})$, lithium $(\mathrm{Li})$ and rubidium $(\mathrm{Rb})$ were carried out by a VARIAN atomic absorption spectrophotometer, model AA $240 \mathrm{FS}$, with a hollow-cathode lamp. The volatile compounds acetaldehyde, ethyl acetate, methanol, n-propanol, 2-methyl-1-propanol and 2methyl-1-butanol+3-methyl-1-butanol were determined by gas chromatography.

Results of physicochemical analyses of minerals and volatile compounds are shown as means of every analysis of base wines and sparkling wines with their respective mean standard deviations. The statistical analysis of results of 
sensory analyses was carried out by the analysis of variance (ANOVA) and by the Tukey's test at 0.05 and 0.01 significance levels.

\section{RESULTS AND DISCUSSION}

Low contents of volatile acidity denote that the base wine had already got previous low contents and that both alcoholic fermentation and foam removal occurred with no development of acetic acid bacteria. High contents of volatile acidity identify wines whose aroma and flavor have been altered. Tables 4, 5 and 6 show that the contents of volatile acidity are low, corroborating with Rognså et al., 2017), except the one of sparkling wine no. 18 (62,50\% Pinot Noir, $18,75 \%$ Merlot and 18,75\% Teroldego). Findings of free and total $\mathrm{SO}_{2}$ contents ensure good wine conservation, in agreement with the Brasil (1988) which recommends maximum content of 350 mg. $\mathrm{L}^{-1}$ (Carbonera, 2010).

The total acidity values of sparkling red wines were in a range between 80.31 to 127.39 , and $\mathrm{pH}$ between 3.10 and 3.50, allowed by Brasil (1988) (Tables 4, 5 and 6). It is worth mentioning that results of $\mathrm{pH}$, total acidity and fixed acidity at different maceration lengths did not differ at the end of the vinification process.

Table 4. Means and standard deviations of results of physicochemical analyses of monovarietal experimental sparkling red wines.

\begin{tabular}{|c|c|c|c|c|c|c|c|c|c|c|c|}
\hline \multirow{2}{*}{ Attribute } & \multicolumn{10}{|c|}{ Sparkling wines } & \multirow[t]{2}{*}{ Mean \pm SP } \\
\hline & 1 & 2 & 3 & 4 & 5 & 6 & 7 & 8 & 9 & 10 & \\
\hline $\begin{array}{c}\text { VA } \\
\left(\mathrm{mEq} \cdot \mathrm{L}^{-1}\right)\end{array}$ & 5.58 & 8.54 & 9.00 & 7.62 & 8.12 & 7.25 & 10.06 & 9.05 & 10.20 & 7.80 & $\begin{array}{c}8.33 \pm \\
1.05\end{array}$ \\
\hline $\begin{array}{c}\text { Free } \mathrm{SO}_{2} \\
\left(\mathrm{mg} . \mathrm{L}^{-1}\right)\end{array}$ & 11.67 & 8.40 & 11.23 & 11.46 & 11.11 & 9.18 & 10.39 & 14.41 & 15.22 & 13.17 & $\begin{array}{c}11.35 \pm \\
1.60\end{array}$ \\
\hline $\begin{array}{l}\text { Total } \mathrm{SO}_{2} \\
\left(\mathrm{mg} \cdot \mathrm{L}^{-1}\right)\end{array}$ & 16.88 & 25.73 & 24.14 & 14.69 & 18.12 & 18.20 & 18.88 & 19.87 & 28.02 & 19.06 & $\begin{array}{c}18.97 \pm \\
3.36\end{array}$ \\
\hline $\begin{array}{c}\text { TTA } \\
\left(\mathrm{mEq} \cdot \mathrm{L}^{-1}\right)\end{array}$ & 80.31 & 99.33 & 81.97 & 91.94 & 98.03 & 103.39 & 102.65 & 93.60 & 124.62 & 115.57 & $\begin{array}{c}98.68 \pm \\
108.65\end{array}$ \\
\hline $\begin{array}{c}\text { FA } \\
\left(\mathrm{mEq} \cdot \mathrm{L}^{-1}\right)\end{array}$ & 74.72 & 90.79 & 72.97 & 84.33 & 89.91 & 96.14 & 92.59 & 84.56 & 114.42 & 107.77 & $\begin{array}{c}90.35 \pm \\
9.53\end{array}$ \\
\hline $\mathrm{pH}$ & 3.43 & 3.46 & 3.42 & 3.42 & 3.30 & 3.31 & 3.26 & 3.32 & 3.13 & 3.23 & $\begin{array}{c}3.32 \pm \\
0.084\end{array}$ \\
\hline $\begin{array}{c}\mathrm{AC} \\
(\% \mathrm{v} / \mathrm{v})\end{array}$ & 13.28 & 13.10 & 13.02 & 12.61 & 11.15 & 11.20 & 10.17 & 11.08 & 11.75 & 11.41 & $\begin{array}{c}11.58 \pm \\
0.90\end{array}$ \\
\hline $\begin{array}{l}\mathrm{RDE} \\
\left(\mathrm{g} . \mathrm{L}^{-1}\right)\end{array}$ & 30.36 & 20.11 & 18.02 & 16.23 & 21.31 & 23.05 & 22.71 & 25.58 & 24.58 & 23.14 & $\begin{array}{c}22.88 \pm \\
2.87\end{array}$ \\
\hline $\begin{array}{c}\mathrm{TT} \\
\left(\mathrm{g} . \mathrm{L}^{-1}\right)\end{array}$ & 0.19 & 0.12 & 0.27 & 0.27 & 0.10 & 0.25 & 0.43 & 0.50 & 0.31 & 0.43 & $\begin{array}{c}0.27 \pm \\
0.10\end{array}$ \\
\hline $\begin{array}{c}\text { TA } \\
\left(\mathrm{mg} \cdot \mathrm{L}^{-1}\right)\end{array}$ & 63.24 & 72.17 & 72.17 & 103.21 & 146.28 & 149.77 & 271.21 & 354.24 & 140.46 & 277.03 & $\begin{array}{c}143.37 \pm \\
81.51\end{array}$ \\
\hline $\begin{array}{c}\text { TPC } \\
(280 \mathrm{~nm})\end{array}$ & 22.40 & 21.30 & 29.60 & 30.50 & 20.90 & 26.10 & 32.20 & 42.00 & 21.50 & 33.40 & $\begin{array}{c}27.85 \pm \\
5.55\end{array}$ \\
\hline O. D. $420 \mathrm{~nm}$ & 0.145 & 0.131 & 0.199 & 0.223 & 0.203 & 0.264 & 0.351 & 0.530 & 0.226 & 0.432 & $\begin{array}{c}0.225 \pm \\
0.100\end{array}$ \\
\hline O. D. $520 \mathrm{~nm}$ & 0.199 & 0.182 & 0.293 & 0.325 & 0.364 & 0.463 & 0.732 & 1.055 & 0.408 & 0.828 & $\begin{array}{c}0.386 \pm \\
0.232\end{array}$ \\
\hline O.D. $620 \mathrm{~nm}$ & 0.040 & 0.03 & 0.053 & 0.064 & 0.051 & 0.075 & 0.102 & 0.190 & 0.061 & 0.131 & $\begin{array}{c}0.063 \pm \\
0.037\end{array}$ \\
\hline TCI & 0.384 & 0.343 & 0.545 & 0.612 & 0.618 & 0.802 & 1.185 & 1.775 & 0.695 & 1.391 & $\begin{array}{c}0.657 \pm \\
0.369\end{array}$ \\
\hline
\end{tabular}

$\mathrm{VA}=$ Volatile Acidity; Free $\mathrm{SO}_{2}=$ Free Sulfur Dioxide; Total $\mathrm{SO}_{2}=$ Total Sulfur Dioxide; TTA = Total Titratable Acidity; FA = Fixed Acidity; $\mathrm{pH}=$ Hydrogenionic Potential; $\mathrm{AC}=$ Alcoholic Content RDE = Reduced Dry Extract; TT = Total Tannins; TA = Total Anthocyanins; TPC $=$ Total Polyphenol Content; O.D. 420nm = Optical Density at 420 nanometers; O.D. 520nm = Optical Density at 520 nanometers; O.D. $620 \mathrm{~nm}=$ Optical Density at 620 nanometers; TCI $=$ Total Color intensity 
Table 5. Means and standard deviations of results of physicochemical analyses of bivarietal experimental sparkling red wines.

\begin{tabular}{|c|c|c|c|c|c|c|c|}
\hline \multirow{2}{*}{ Attribute } & \multicolumn{6}{|c|}{ Sparkling wines } & \multirow{2}{*}{ Mean \pm SD } \\
\hline & 11 & 12 & 13 & 14 & 15 & 16 & \\
\hline $\begin{array}{c}\text { VA } \\
\left(\mathrm{mEq} \cdot \mathrm{L}^{-1}\right)\end{array}$ & 9.28 & 6.74 & 7.38 & 8.17 & 7.43 & 8.68 & $7.8 \pm 0.76$ \\
\hline $\begin{array}{c}\text { Free } \mathrm{SO}_{2} \\
\left(\mathrm{mg} \cdot \mathrm{L}^{-1}\right)\end{array}$ & 11.83 & 14.14 & 12.31 & 13.52 & 11.47 & 12.19 & $12.25 \pm 0.84$ \\
\hline $\begin{array}{l}\text { Total } \mathrm{SO}_{2} \\
\left(\mathrm{mg} . \mathrm{L}^{-1}\right)\end{array}$ & 20.75 & 24.74 & 25.82 & 22.57 & 17.31 & 22.91 & $22.74 \pm 2.21$ \\
\hline $\begin{array}{c}\text { TTA } \\
\left(\mathrm{mEq} \cdot \mathrm{L}^{-1}\right)\end{array}$ & 92.86 & 91.02 & 102.65 & 96.93 & 127.39 & 118.53 & $99.79 \pm 12.04$ \\
\hline $\begin{array}{c}\text { FA } \\
\left(\mathrm{mEq} \cdot \mathrm{L}^{-1}\right)\end{array}$ & 83.59 & 84.28 & 95.26 & 88.76 & 119.96 & 109.85 & $92.01 \pm 11.97$ \\
\hline $\mathrm{pH}$ & 3.38 & 3.35 & 3.31 & 3.32 & 3.24 & 3.29 & $3.32 \pm 0.04$ \\
\hline $\begin{array}{c}\mathrm{AC} \\
(\% \mathrm{v} / \mathrm{v})\end{array}$ & 12.38 & 11.90 & 12.71 & 12.20 & 11.32 & 11.23 & $12.05 \pm 0.47$ \\
\hline $\begin{array}{l}\text { RDE } \\
\left(\mathrm{g} \cdot \mathrm{L}^{-1}\right)\end{array}$ & 21.84 & 21.37 & 28.79 & 21.95 & 18.83 & 21.85 & $21.85 \pm 2.12$ \\
\hline $\begin{array}{c}\mathrm{TT} \\
\left(\mathrm{g} . \mathrm{L}^{-1}\right)\end{array}$ & 0.19 & 0.41 & 0.14 & 0.23 & 0.39 & 0.95 & $0.31 \pm 0.20$ \\
\hline $\begin{array}{c}\text { TA } \\
\left(\mathrm{mg}^{-\mathrm{L}^{-1}}\right)\end{array}$ & 117.56 & 140.07 & 77.99 & 182.36 & 159.86 & 359.68 & $149.97 \pm 65.40$ \\
\hline $\begin{array}{c}\text { TPC } \\
(280 \mathrm{~nm})\end{array}$ & 22.90 & 32.70 & 20.80 & 31.10 & 19.60 & 32.00 & $27.00 \pm 5.42$ \\
\hline D.O. $420 \mathrm{~nm}$ & 0.230 & 0.331 & 0.176 & 0.303 & 0.257 & 0.493 & $0.280 \pm 0.077$ \\
\hline O. D. $520 \mathrm{~nm}$ & 0.364 & 0.586 & 0.274 & 0.526 & 0.467 & 0.997 & $0.497 \pm 0.171$ \\
\hline O. D. $620 \mathrm{~nm}$ & 0.073 & 0.106 & 0.050 & 0.094 & 0.079 & 0.200 & $0.087 \pm 0.035$ \\
\hline TCI & 0.667 & 1.023 & 0.500 & 0.923 & 0.803 & 1.690 & $0.863 \pm 0.281$ \\
\hline
\end{tabular}

VA = Volatile Acidity; Free $\mathrm{SO}_{2}=$ Free Sulfur Dioxide; Total $\mathrm{SO}_{2}=$ Total Sulfur Dioxide; TTA = Total Titratable Acidity; FA = Fixed Acidity; $\mathrm{pH}=$ Hydrogenionic Potential; $\mathrm{AC}=$ Alcoholic Content $\mathrm{RDE}=$ Reduced Dry Extract ;T $=$ Total Tannins; $\mathrm{TA}=\mathrm{Total}$ Anthocyanins; TPC = Total Polyphenol Content; O.D. 420nm = Optical Density at 420 nanometers; O.D. 520nm = Optical Density at 520 nanometers; O.D. $620 \mathrm{~nm}=$ Optical Density at 620 nanometers; TCI $=$ Total Color intensity

Table 6. Means and standard deviations of results of physicochemical analyses of trivarietal experimental sparkling red wines.

\begin{tabular}{|c|c|c|c|c|c|c|c|}
\hline \multirow{2}{*}{ Attribute } & \multicolumn{6}{|c|}{ Sparkling wines } & \multirow{2}{*}{ Mean \pm SD } \\
\hline & 11 & 12 & 13 & 14 & 15 & 16 & \\
\hline $\begin{array}{c}\text { VA } \\
\left(\mathrm{mEq} . \mathrm{L}^{-1}\right)\end{array}$ & 8.95 & 12.83 & 9.97 & 8.91 & 9.78 & 7.62 & $9.37 \pm 1.18$ \\
\hline $\begin{array}{l}\text { Free } \mathrm{SO}_{2} \\
\left(\mathrm{mg} . \mathrm{L}^{-1}\right)\end{array}$ & 10.97 & 10.19 & 13.17 & 10.71 & 11.29 & 11.28 & $11.13 \pm 0.65$ \\
\hline $\begin{array}{l}\text { Total } \mathrm{SO}_{2} \\
\left(\mathrm{mg} . \mathrm{L}^{-1}\right)\end{array}$ & 20.40 & 14.62 & 15.00 & 13.66 & 20.81 & 24.37 & $17.70 \pm 3.72$ \\
\hline $\begin{array}{c}\text { TTA } \\
\left(\mathrm{mEq} . \mathrm{L}^{-1}\right)\end{array}$ & 101.17 & 102.65 & 105.23 & 107.26 & 111.14 & 110.77 & $106.25 \pm 3.35$ \\
\hline $\begin{array}{c}\mathrm{FA} \\
\left(\mathrm{mEq} \cdot \mathrm{L}^{-1}\right)\end{array}$ & 92.22 & 89.82 & 95.26 & 98.36 & 101.36 & 103.16 & $96.81 \pm 4.26$ \\
\hline $\mathrm{pH}$ & 3.36 & 3.34 & 3.31 & 3.31 & 3.23 & 3.27 & $3.31 \pm 0.04$ \\
\hline $\begin{array}{c}\mathrm{AC} \\
(\% \mathrm{v} / \mathrm{v})\end{array}$ & 12.51 & 12.36 & 11.75 & 11.39 & 11.84 & 11.72 & $11.80 \pm 0.34$ \\
\hline $\begin{array}{l}\text { RDE } \\
\left(\mathrm{g} \cdot \mathrm{L}^{-1}\right)\end{array}$ & 20.87 & 21.37 & 18.20 & 19.97 & 19.31 & 20.93 & $20.42 \pm 0.95$ \\
\hline $\begin{array}{c}\mathrm{TT} \\
\left(\mathrm{g} . \mathrm{L}^{-1}\right)\end{array}$ & 0.35 & 0.68 & 0.41 & 0.73 & 0.21 & 0.77 & $0.55 \pm 0.20$ \\
\hline
\end{tabular}




$\begin{array}{cccccccc}\begin{array}{c}\text { TA } \\ \left(\mathrm{mg} . \mathrm{L}^{-1}\right)\end{array} & 96.61 & 145.50 & 151.71 & 263.06 & 119.89 & 245.60 & 148.61 \pm 55.96 \\ \begin{array}{c}\text { TPC } \\ (280 \mathrm{~nm})\end{array} & 20.70 & 32.90 & 20.20 & 32.70 & 18.60 & 31.30 & 26.00 \pm 6.23 \\ \text { D.O. } 420 \mathrm{~nm} & 0.205 & 0.329 & 0.246 & 0.456 & 0.225 & 0.446 & 0.288 \pm 0.093 \\ \text { O. D. } 520 \mathrm{~nm} & 0.349 & 0.567 & 0.440 & 0.849 & 0.397 & 0.813 & 0.504 \pm 0.175 \\ \text { O. D. } 620 \mathrm{~nm} & 0.064 & 0.124 & 0.077 & 0.189 & 0.071 & 0.178 & 0.101 \pm 0.047 \\ \text { TCI } & 0.618 & 1.020 & 0.763 & 1.494 & 0.693 & 1.437 & 0.892 \pm 0.313\end{array}$

VA = Volatile Acidity; Free $\mathrm{SO}_{2}=$ Free Sulfur Dioxide; Total $\mathrm{SO}_{2}=$ Total Sulfur Dioxide; TTA = Total Titratable Acidity; FA = Fixed Acidity; $\mathrm{pH}=$ Hydrogenionic Potential; $\mathrm{AC}=$ Alcoholic Content $\mathrm{RDE}=$ Reduced Dry Extract TT $=$ Total Tannins; TA $=$ Total Anthocyanins; TPC = Total Polyphenol Content; O.D. 420nm = Optical Density at 420 nanometers; O.D. 520nm = Optical Density at 520 nanometers; O.D. $620 \mathrm{~nm}=$ Optical Density at 620 nanometers; TCI $=$ Total Color intensity

Sparkling wines usually have low contents of reduced dry extract because they are produced with the reduced participation of the grape membrane and as the result of how must is extracted. Ribéreau-Gayon et al. (2003) found contents which ranged from 16.0 g.L $\mathrm{L}^{-1}$ to 18.0 g.L $\mathrm{L}^{-1}$, on average. However, in the study reported by this paper, the grape membrane kept longer in contact with the most during its extraction than the normal length used in sparkling white wine production; thus, contents kept above average.

Results of analyses of the total polyphenol content showed differences between both maceration lengths, i.e., it was higher in SM for all sparkling wines (Tables 4, 5 and 6). A number of studies have investigated the extraction behaviour of phenolic compounds during the maceration. GómezMíguez et al. (2007) reported higher extraction rates of anthocyanins than for other phenolic compounds (De Santis and Frangipane, 2010). Increase in the number of maceration hours leads to an increase in this content. Anthocyanins are easily extracted since they are in the vacuoles of the most external cells of the membrane. Simple crushing of grapes is enough to extract them, thus, even though their concentration is higher in SM, satisfactory color can be obtained in VSM (Tables 4, 5 and 6).

Wines that went through SM had their solid part in contact with their liquid one for more time; hence, higher tannin concentrations (Tables 4, 5 and 6). Studies have shown that overall intensity and persistence are positively correlated with astringency, and therefore to tannin content. A relationship between tannin content and allocation grade has also been described (Mercurio et al., 2010).

The young red wines show a maximum absorbance value at $520 \mathrm{~nm}$, corresponding to the red color, a yellow component at $420 \mathrm{~nm}$ and a blue component at $620 \mathrm{~nm}$, that are important to describe its color. For this reason, the young wine has a deep red color with violet tonalities that evolves to a red tile color and then to brown during its traditional aging, due to a decrease in the red component and an increase in the yellow component (Zamora, 2013). In our study, the sparkling wines that obtained the highest values of total color intensity were those subjected to SM, with a higher extraction of total polyphenols (Tables 4, 5 and 6). Similarly, Gambuti et al. (2013) observed a slight decrease of color in wines with less total polyphenols.

Regarding minerals that are wines constituents (Table 7), SM enabled the highest release of $\mathrm{K}$, whose content usually represents from $40 \%$ to $60 \%$ of minerals in wine and, in this study, average was about $1025 \mathrm{mg} . \mathrm{L}^{-1}$. Although the concentration of $\mathrm{K}$ is related to the soil, plant, weather conditions and vinification system, its final content depends on the ionic balance that occurs in the wine. $\mathrm{Ca}$ is a natural constituent of wine. Its determination is needed to monitor precipitation of $\mathrm{Ca}$ bitartrate, a process which occurs slowly in bottled wine. One of the factors that is responsible for the increase in its content is the spraying of bordeaux syrup on vineyards to control fungal diseases. Therefore, differences in $\mathrm{Ca}$ contents in the wines may have resulted from the spraying and from the weather conditions at grape maturation and harvest periods. Average was about $63 \mathrm{mg} . \mathrm{L}^{-1}$, but the longer the maceration length, the more it increased. The average content of $\mathrm{Mg}$ is usually higher than the one of $\mathrm{Ca}$ because its salts are more soluble. Its average concentration was about 86 mg. $L^{-1}$.

Concentrations of sodium (Na), phosphorus $(\mathrm{P})$, copper $(\mathrm{Cu})$ had means of $18.5 \mathrm{mg} . \mathrm{L}^{-1} ; 65.4$ $\mathrm{mg} . \mathrm{L}^{-1}$ and $2.9 \mathrm{mg} . \mathrm{L}^{-1}$ respectively. Iron $(\mathrm{Fe})$, zinc $(\mathrm{Zn})$, rubidium $(\mathrm{Rb})$ and lithium $(\mathrm{Li})$ presented means of $1.0 \mathrm{mg} . \mathrm{L}^{-1} ; 1.9 \mathrm{mg} . \mathrm{L}^{-1} ; 1.6 \mathrm{mg} . \mathrm{L}^{-1}$ e 1.9 $\mu \mathrm{g} . \mathrm{L}^{-1}$, respectively. This minerals were not affected by the intensity of the maceration processes (values not show). 
Table 7. Means and standard deviations of results of potassium $(\mathrm{K})$, calcium $(\mathrm{Ca})$ e magnesium $(\mathrm{Mg})$ analyses of experimental sparkling red wines.

\begin{tabular}{cccc} 
Sparkling Wines & \multicolumn{3}{c}{$\left(\mathrm{mg} . \mathrm{L}^{-1}\right)$} \\
\cline { 2 - 4 } & $\mathrm{K}$ & $\mathrm{Ca}$ & $\mathrm{Mg}$ \\
\hline 1 & 911.2 & 51.2 & 89.3 \\
3 & 1176.1 & 55.3 & 86.3 \\
4 & 995.9 & 55.6 & 94.5 \\
5 & 1070.1 & 58.1 & 87.3 \\
6 & 1038.3 & 57.0 & 73.6 \\
7 & 1123.1 & 58.6 & 73.4 \\
8 & 1070.1 & 61.6 & 76.1 \\
9 & 1091.3 & 62.1 & 76.3 \\
10 & 805.2 & 75.9 & 96.9 \\
11 & 985.3 & 86.0 & 101.5 \\
12 & 1101.9 & 55.8 & 80.8 \\
13 & 1070.1 & 58.5 & 83.2 \\
14 & 953.3 & 62.7 & 93.0 \\
15 & 974.7 & 67.6 & 96.4 \\
16 & 1006.5 & 64.3 & 83.3 \\
17 & 1070.1 & 71.5 & 86.7 \\
18 & 1038.3 & 58.5 & 87.3 \\
19 & 1038.3 & 62.2 & 90.2 \\
20 & 1027.7 & 59.8 & 82.3 \\
21 & 1059.5 & 63.4 & 84.1 \\
22 & 932.4 & 66.9 & 90.6 \\
\hline
\end{tabular}

Mean \pm SD $1025.3 \pm 79.56$

$63.1 \pm 87.8$

$86.2 \pm 7.61$

Regarding volatile compounds, decrease in acetaldehyde was observed in all experimental sparkling wines as maceration developed. Chemical oxidation of wine largely results in the oxidation of ethanol to acetaldehyde. The rate of this reaction is mainly dependent on the concentration of sulfur dioxide or other antioxidants such as glutathione (Gambuti et al., 2015) and the level of reactive polyphenols available in wine (Picariello et al., 2017). As a result, if its concentrations are higher than $50 \mathrm{mg} \cdot \mathrm{L}^{-1}$, it shows that the wine is oxidized. None of the sparkling wines under investigation showed evidence of being oxidized, since average concentration was $16 \mathrm{mg} . \mathrm{L}^{-1}$.

Methanol is always found in wines in little amounts, between 60 and $150 \mathrm{mg} \cdot \mathrm{L}^{-1}$. This alcohol results exclusively from the hydrolysis of pectins carried out by enzyme activity. Even though it is toxic at high concentrations (DL $\left.50=350 \mathrm{mg} \cdot \mathrm{L}^{-1}\right)$, methanol does not reach high values when normal vinification practices are followed. Methanol in the $100 \%$ Merlot (SM) was found to be above acceptable values ( $\left.258 \mathrm{mg} . \mathrm{L}^{-1}\right)$, a fact that may have affected the final quality of the product. The volatile compounds n-Propanol, 2-Methyl-1-Propanol and Amyl Alcohols were not affected by different maceration lengths.

In the sensory evaluation of wines, the color and the violet tonality were always more intense in wines that underwent SM, differing significantly at $1 \%$ probability of error (Figure 1). It is worth highlighting that the sparkling wines with the highest grades in color intensity and hue were no.10 in the group of monovarietals, no. 16 among bivarietals and both no. 20 no. 22 among trivarietals. It corroborated results found in the physicochemical analyses and the tasters preferences. 


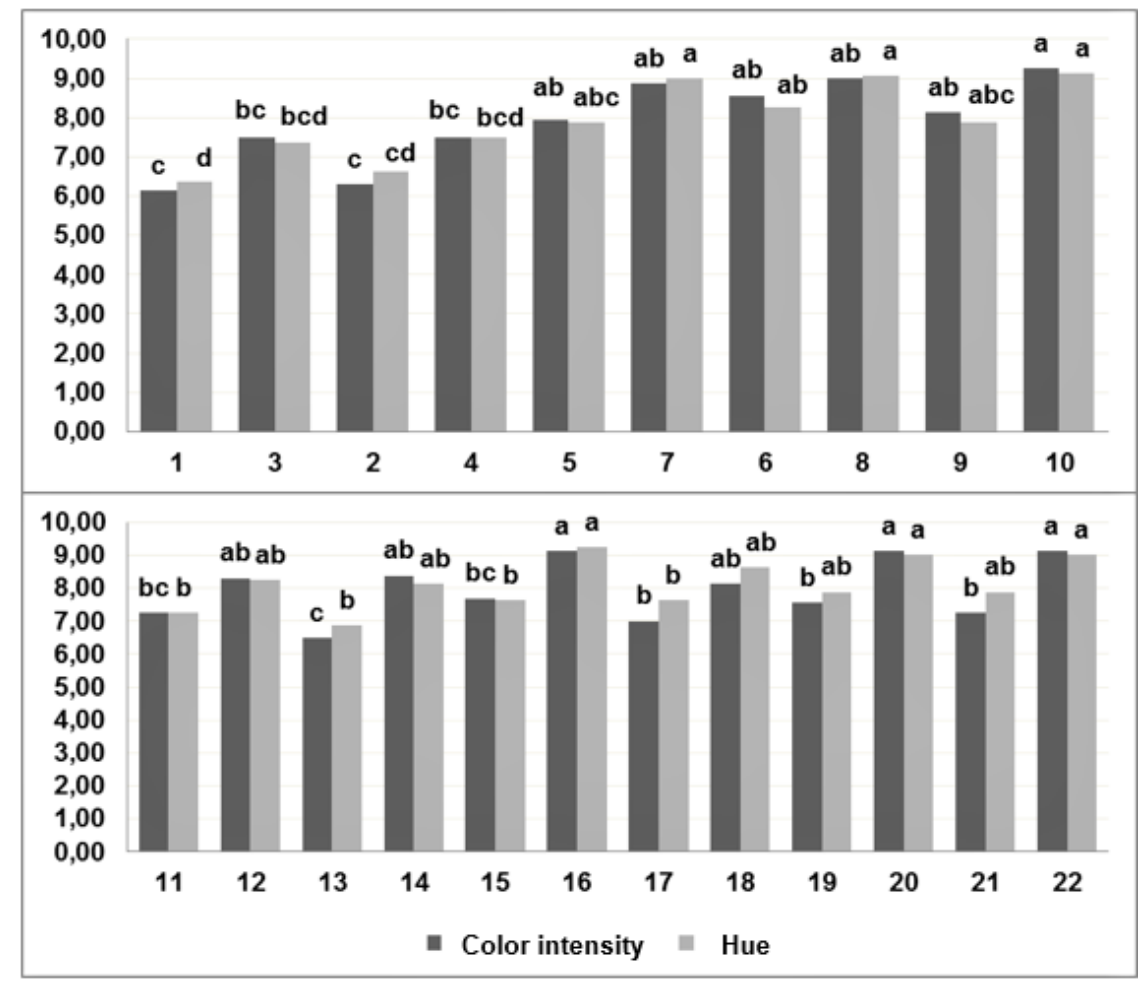

Figure 1. Graph of significant statistical differences in color among experimental sparkling wines, according to the Tukey's test at $1 \%$ probability of error.

The amount, size and persistence of perlage were also observed. Mean scores attributed to sensory analysis were 7.64 for monovarietal, 8 for bivarietal and 8 for trivarietal wines with no statistical differences between both maceration lengths.

Concerning olfactory senses, both intensity and quality of the aroma were investigated, besides the main aroma descriptor of every sparkling wine. Average grades about 7.5 and 8 were attributed to aroma intensity and aroma quality, respectively. According to the descriptive methodology, both fruity and vegetal aromas were perceived in all sparkling wines under analysis.

In the case of monovarietal sparkling wines, the main aroma descriptors were fruity, red fruits and vegetal. The highest grades were given to sparkling wines no. 7, no. 9 and no. 10 (Table 8). Bivarietal sparkling wines also emphasized fruity, red fruits and vegetal descriptors and the highest grades were attributed to sparkling wines no. 11 and no. 13 Teroldego (Table 9). Regarding trivarietal sparkling wines, the same descriptors were highlighted but no defects were mentioned (Table 10). Sparkling wines no. 17 , no. 19 and no. 22 got the highest grades in this group.

Besides the main descriptors, aroma of tropical fruits, yeast, jam, citric, ripe grape, cognac, fig and volatile acidity were also mentioned.

Table 8. Main aroma descriptors found by wine tasters in monovarietal sparkling wines, with number of mentions.

\begin{tabular}{|c|c|c|c|c|c|c|c|c|c|c|}
\hline \multirow{2}{*}{ Aroma descriptors } & \multicolumn{10}{|c|}{ Sparkling wines } \\
\hline & 1 & 2 & 3 & 4 & 5 & 6 & 7 & 8 & 9 & 10 \\
\hline Fruity & 2 & 2 & 1 & 1 & 1 & 2 & 2 & 1 & 2 & 4 \\
\hline Red fruits & 4 & 2 & & & & 2 & 1 & 1 & 4 & 3 \\
\hline Floral & & 1 & & & 1 & & 1 & & & \\
\hline Vegetal & & 1 & 2 & 4 & 3 & 3 & 4 & 3 & 3 & 2 \\
\hline Sarment & & & 2 & 2 & 1 & & 1 & & & \\
\hline Neutral & & 1 & & & 1 & & & & & \\
\hline Sulfurous & & & & & & & & 5 & & \\
\hline Herbal & & & & & 1 & & & 1 & & 1 \\
\hline
\end{tabular}


Table 9. Main aroma descriptors found by wine tasters in bivarietal sparkling wines, with number of mentions.

\begin{tabular}{lllllll}
\hline \multirow{2}{*}{ Aroma descriptors } & \multicolumn{7}{c}{ Sparkling wines } \\
& 11 & 12 & 13 & 14 & 15 & 16 \\
\hline Fruity & 2 & 2 & 5 & 1 & & 2 \\
Red fruits & 3 & 4 & 2 & 3 & 1 & 2 \\
Ripe fruits & & 1 & & 1 & & 1 \\
Tropical fruits & 3 & & 1 & & & 1 \\
Yeast & 3 & 1 & 1 & 1 & 1 & 1 \\
Floral & 3 & 2 & 2 & 2 & 5 & 3 \\
Vegetal & & 1 & & & 1 & 1 \\
Neutral & & 1 & & 1 & & 1 \\
Sarment & & & & & \\
\hline
\end{tabular}

Table 10. Main aroma descriptors found by wine tasters in trivarietal sparkling wines, with number of mentions.

\begin{tabular}{lllllll}
\hline \multirow{2}{*}{ Aroma descriptors } & \multicolumn{5}{c}{ Sparkling wines } \\
& 17 & 18 & 19 & 20 & 21 & 22 \\
\hline Fruity & 2 & 2 & 2 & 2 & 3 & 3 \\
Red fruits & 4 & 1 & 3 & 1 & & 1 \\
Ripe fruits & 1 & 1 & & & & \\
Dry fruits (almond) & 1 & 1 & & & & 1 \\
Raisin & & & 1 & & 2 & 1 \\
Yeast & 2 & & 2 & 2 & 2 & 3 \\
Vegetal & 1 & 1 & 1 & 3 & 2 \\
\hline
\end{tabular}

Besides the main descriptors, aroma of coffee, smoke, jam, spices (pepper), sulphur and volatile acidity were also mentioned.

Besides the main descriptors, aroma of tropical fruits, citrine, pepper, dry fungus and sarment were also mentioned.

In most evaluations related to taste, no significant statistical differences were perceived among sparkling wines in the grades given by tasters. However, significant statistical differences may be observed at $1 \%$ probability of error in the case of the variable defect in sparkling wine no. 8 . Such attribute may have negatively affected the variables olfactory-gustatory harmony and general quality, which had significant differences at $1 \%$ and at $5 \%$, respectively, but they were lower in the case of sparkling wine no. 8

\section{CONCLUSIONS}

Teroldego were the vinification parameters that provided the best olfactory-gustatory and color characteristics to the sparkling wines under study.

All sparkling wines have enological potential to be vinified in red.

Both maceration lengths under investigation are able to produce sparkling red wines with freshness, high intrinsic quality and no technological defects.

RESUMO: A maceração é a etapa da vinificação na qual os compostos fenólicos e aromáticos são transferidos ao vinho. O objetivo deste trabalho foi produzir espumantes finos tintos testando a variedade de uva e a duração da maceração. As uvas sofreram maceração por 24 horas (Maceração Muito Curta - MMC) e por 48 horas (Maceração Curta MC). Os espumantes foram produzidos com o método tradicional e as análises realizadas nos mostos, vinhos base e espumantes. Foram realizadas análises de minerais, de compostos voláteis e físico-químicas relacionadas a sólidos solúveis totais (SST), acidez volátil (AV), acidez total (AcT), dióxido de enxofre livre $\left(\mathrm{SO}_{2} \mathrm{~L}\right)$ e total $\left(\mathrm{SO}_{2} \mathrm{~T}\right)$, acidez fixa $(\mathrm{AF})$, potencial hidrogeniônico $(\mathrm{pH})$, teor alcoólico (TA), extrato seco (ES), extrato seco reduzido (ESR), índice de polifenóis totais (IPT), antocianinas totais (AT), taninos totais (TT) e intensidade total da cor (ITC). Além disso, durante a degustação, uma ficha quantitativa e descritiva foi distribuída aos pesquisadores para caracterizar os vinhos em relação à cor, perlage, aroma, sabor, principal descritor do aroma e principal adjetivo geral. Nas diferentes macerações, os espumantes que obtiveram melhores avaliações foram: 100\% Teroldego (MC) e 62,5\% Teroldego, 18,75\% Merlot e 18,75\% Pinot Noir (MC). Indicando que a maceração curta e a variedade Teroldego foram os parâmetros de vinificação que proporcionaram melhores características olfato-gustativas e de coloração aos espumantes estudados. Excetuando-se o espumante $100 \%$ Merlot (MC), todos demonstraram possuir potencial enológico para serem vinificados em tinto e as maturações e macerações testadas produziram o frescor característico dos espumantes e a coloração tinta desejada. 
PALAVRAS CHAVE: Espumante tinto. Maceração. Enologia. Polifenóis.

\section{REFERENCES}

ALEIXANDRE-TUDO, J. L., BUICA, A., NIEUWOUDT, H., ALEIXANDRE, J. L., DU TOIT, W. Spectrophotometric Analysis of Phenolic Compounds in Grapes and Wines. Journal of Agricultural and Food Chemistry, v. 65, n. 20, p. 4009-4026, 2017. https://doi.org/10.1021/acs.jafc.7b01724

BAVČAR D., BAŠA ČESNIK H.,ČUŠ F., KOŠMERL T. The influence of skin contact during alcoholic fermentation on the aroma composition of Ribolla Gialla and Malvasia Istriana Vitis vinifera (L.) grape wines. International Journal of Food Science and Technology, v. 46, p. 1801-1808, 2011. https://doi.org/10.1111/j.1365-2621.2011.02679.x

BRASIL. Ministério da Agricultura, Pecuária e Abastecimento. Portaria 229. Aprova a norma referente à complementação dos padrões de identidade e qualidade do vinho. 1988. 11p.

CADOT, Y., CAILLÉ, S., SAMSON, A., BARBEAU, G., CHEYNIER, V. Sensory representation of typicality of Cabernet franc wines related to phenolic composition: Impacto of ripening stage and maceration. Analytica Chimica Acta, v. 732, p. 91-99, 2012. https://doi.org/10.1016/j.aca.2012.02.013

CARBONERA, A. M. Relatório de Estágio na Vinícola Wine Park: Uma Visão da Elaboração de Vinhos, Espumantes e Suco de Uva. 2010. 49f. Trabalho de Conclusão de Curso. Instituto Federal de Educação, Ciência e Tecnologia do Rio Grande do Sul. Bento Gonçalves, 2010.

CASASSA, L. F., HARBERTSON, J. F. Extraction, Evolution, and Sensory Impact of Phenolic Compounds During Red Wine Maceration. The Annual Review of Food Science and Technology. 2014. https://doi.org/10.1146/annurev-food-030713-092438

CASASSA LF, BEAVER CW, MIRELES MS, HARBERTSON JF. Effect of extended maceration and ethanol concentration on the extraction and evolution of phenolics, color components and sensory attributes of Merlot wines. Aust. J. Grape Wine Res. v. 19, p. 25-39, 2013. https://doi.org/10.1111/ajgw.12009

CVEJIĆ J., PUŠKAŠ V., MILJIĆ U. Varietal phenolic composition of Probus, Rumenika and Frankovka red wines from Fruška Gora (Serbia) and changes in main compounds during maceration, European Food Research Technology. v.242, p. 1319, 2016. https://doi.org/10.1007/s00217-016-2635-y

DE SANTIS D., FRANGIPANE M. T. Effect of prefermentative cold maceration on the aroma 531 and phenolic profiles of a Merlot red wine. Italian Journal of Food Science, v. 22, n. 1, p. 47-53, 2010.

FERRER-GALLEGO, R., HERNÁNDEZ-HIERRO, J. M., RIVAS-GONZALO, J. C., ESCRIBANOBAILÓN, M. T. Influence of climatic conditions on the phenolic composition of Vitis vinifera L. cv. Graciano. Analytica Chimica Acta, v. 732, p. 73-77, 2012. https://doi.org/10.1016/j.aca.2011.12.072

GAMBUTI, A., HAN, G., PETERSON, A. L., WATERHOUSE, A. L. Sulfur dioxide and glutathione alter the outcome of microoxygenation. American Journal of Enology and Viticulture, v. 66, n. 4, p. 411-423, 2015. https://doi.org/10.5344/ajev.2015.15005

GAMBUTI, A., RINALDI, A., UGLIANO, M., \& MOIO, L. Evolution of phenolic compounds and astringency during aging of red wine: effect of oxygen exposure before and after bottling. Journal Agriculture and Food Chemistry. v. 61, p. 1618-1627, 2013. https://doi.org/10.1021/jf302822b

GIL M, KONTOUDAKIS N, GONZALEZ E, ESTERUELAS M, FORT F. Influence of grape maturity and mac- ' eration length on color, polyphenolic composition, and polysaccharide content of Cabernet Sauvignon and Tempranillo wines. J. Agric. Food Chem. v. 60, p. 7988-8001, 2012. https://doi.org/10.1021/jf302064n 
GÓMEZ-MÍGUEZ, M. J., GONZÁLEZ-MIRET, M. L., HERNANZ, D., FERNÁNDEZ, M. Á., VICARIO, I. M., \& HEREDIA, F. J. Effects of prefermentative skin contact conditions on colour and phenolic content 556 of white wines. Journal of Food Engineering, v. 78, n. 1, p. 238-245, 2007.

https://doi.org/10.1016/j.jfoodeng.2005.09.021

GONZALEZ-NEVES G, GIL G, FAVRE G, FERRER M. Influence of grape composition and winemaking on the ' anthocyanin composition of red wines of Tannat. Int. J. Food Sci. Tech. v. 47, p. 1-10, 2012. https://doi.org/10.1111/j.1365-2621.2011.02920.x

HE, F., LIANG, N. N., MU, L., PAN, Q. H., WANG, J., REEVES, M. J., \& DUAN, C. Q. Anthocyanins and their variation in red wines II. Anthocyanin derived pigments and their color evolution. Molecules, v. 17, n. 2, p. 1483-1519, 2012. https://doi.org/10.3390/molecules17021571

LUKIĆ I., JEDREJČIĆ N., GANIĆ K. K., STAVER M. AND PERŠURIĆ D. Composition of White Wine aft er Prolonged Maceration and Maturation, Food Technol. Biotechnol. v.53, n. 3, p. 407-418, 2015.

MELÉNDEZ, E., ORTIZ, M. C., SARABIA, L. A., ÍNNIGUEZ, M., \& PURAS, P. Modelling phenolic and technological maturities of grapes by means of the multivariate relation between organoleptic and physicochemical properties. Analytica Chimica Acta, v. 761, p. 53-61, 2013.

https://doi.org/10.1016/j.aca.2012.11.021

MERCURIO, M. D., DAMBERGS, R. G., COZZOLINO, D., HERDERICH, M. J., \& SMITH, P. A. Relationship between red wine grades and phenolics. 1. Tannin and total phenolics concentrations. Journal of Agricultural and Food Chemistry, v. 58, p. 12313-12319, 2010. https://doi.org/10.1021/jf103230b

PICARIELLO, L., GAMBUTI, A., PICARIELLO, B., MOIO, L. Evolution of pigments, tannins and acetaldehyde during forced oxidation of red wine: Effect of tannins addition. LWT - Food Science and Technology, v. 77, p. 370-375, 2017. https://doi.org/10.1016/j.lwt.2016.11.064,

RADEKA S, HERJAVEC S, PERŠURIĆ Đ, LUKIĆ I, SLADONJA B. Effect of different maceration treatments on free and bound varietal aroma compounds in wine of Vitis vinifera L. cv. Malvazij a istarska bij ela. Food Technol Biotechnol. v. 46, p. 86-92, 2008.

RIBÉREAU-GAYON, P., DUBOURDIEU, D., DONÈCHE, B., LONVAUD, A. Tratado de enologia: Microbiología del vino.Vinificaciones. Buenos Aires; Mundi-Prensa, 2003. 655p.

RIZZON, L. Análise sensorial dos vinhos. RIZZON, L. A. (Ed.). Metodologia para análise de vinho. Brasília, DF, Embrapa Informação Tecnológica; Bento Gonçalves: Embrapa Uva e Vinho, 2010. p. 9-12

RODRIGUEZ-BENCOMO, J. J., MENDEZ-SIVERIO, J. J., PÉREZ-TRUJILLO, J. P., \& CACHO, J. Effect of skin contact on bound aroma and free volatiles of Listan blanco wine. Food Chemistry, v. 110, p. 214-225, 2008. https://doi.org/10.1016/j.foodchem.2008.01.037

ROGNSÅ G. H., RATHE M., PETERSEN M. A., MISJE K.E., HERSLETH M., SIVERTSVIK M., RISBO J. From wine to wine reduction: Sensory and chemical aspects. International Journal of Gastronomy and Food Science. v. 9, p. 62-74, 2017. https://doi.org/10.1016/j.ijgfs.2017.06.006

SMITH, P. A., MCRAE, J. M., \& BINDON, K. A. Impact of winemaking practices on the concentration and composition of tannins in red wine. Australian Journal of Grape and Wine Research, v. 21, p. 601-614, 2015. https://doi.org/10.1111/ajgw.12188

YILMAZTEKIN, M., KOCABEY, N., \& HAYALOGLU, A. A. Effect of maceration time on free and bound volatiles of red wines from cv. Karaoglan (Vitis vinifera L.) grapes grown in Arapgir, Turkey. Journal of Food Science, v. 80, p. 556-563, 2015. https://doi.org/10.1111/1750-3841.12767

ZAMORA, F. La química del color del vino. Revista ACE. Dossier 18 dic 2013. 